\title{
Introduction potential of GPS navigation technology for supervision control at capital construction, reconstruction and conversion projects
}

\author{
Dmitriy Topchiy ${ }^{1, *}$, Alexey Yurgaytis ${ }^{1}$ and Dmitriy Yurgaytis $^{2}$ \\ ${ }^{1}$ Moscow State University of Civil Engineering, 129337, 26, Yaroslavskoye Shosse, Moscow, Russia \\ ${ }^{2}$ Lomonosov Moscow State University, 129305, 22, Lomonosovsky Avenue, Moscow, Russia
}

\begin{abstract}
This article analyzes potential use of various navigation technologies to implement building supervision functions for capital construction, reconstruction and conversion projects. It indicates the basic prerequisites for the development of such technologies and describes the navigation physical principle applicable due to its properties for a certain range of supervision functions in the construction industry. The article also examines testing of corresponding software systems on the construction sites in Moscow in control operations by the Technical Customer's engineers, and analyzes the potential of using adjacent navigation systems for similar purposes as compared with the main physical and technical characteristics of implementation in professional software packages.
\end{abstract}

\section{Introduction}

The following is the definition of the systems science that now offers additional possibilities of developing human activities in a number of areas including the construction industry. Navigation (Latin navigatio, from Latin navigo - 'I go by boat') is a field of study that focuses on methods to determine velocity, location and orientation of moving objects; it has evolved as a result of the general ship navigation study development (Table 1). In the modern world, it is virtually impossible to imagine human life without the navigation technology - navigation systems enable safe cargo and passenger transportation by air, sea and land; coordination of space devices and rescue operations; meeting the requirement of online tracking in large cities and heavy urban traffic, etc [1-2].

Table 1. Milestones of navigation science development.

\begin{tabular}{|l|l|l|l|}
\hline $\begin{array}{c}\text { Item } \\
\text { No. }\end{array}$ & Historical period & \multicolumn{1}{|c|}{ Location } & \multicolumn{1}{c|}{ Event } \\
\hline 1. & $\begin{array}{l}\text { Ancient World } \\
\text { (6th century B.C.) }\end{array}$ & $\begin{array}{l}\text { Ancient } \\
\text { Greece }\end{array}$ & $\begin{array}{l}\text { The properties of magnetic iron ore are described } \\
\text { by Thales of Miletus for the first time ever }\end{array}$ \\
\hline 2. & $\begin{array}{l}\text { Middle Ages (11th } \\
\text { century; } ~\end{array}$ & $\begin{array}{l}\text { China, Song } \\
\text { dynasty }\end{array}$ & $\begin{array}{l}\text { In his work 'The Four Great Chinese Inventions' } \\
\text { Joseph Nidem, researcher of Chinese and ancient }\end{array}$ \\
\hline
\end{tabular}

* Corresponding author: dvtopchiy0405@gmail.com 


\begin{tabular}{|c|c|c|c|}
\hline & 1044) & & $\begin{array}{l}\text { Chinese science, mentions among other } \\
\text { inventions (paper, gunpowder, book printing) the } \\
\text { first magnetic device determining an object's } \\
\text { location (i.e. compass) to facilitate navigation } \\
\text { along with maps and pilot charts used in sea } \\
\text { voyages. }\end{array}$ \\
\hline 3. & $\begin{array}{l}\text { Middle Ages (12th - } \\
\text { 13th century) }\end{array}$ & Europe & $\begin{array}{l}\text { First prototypes of the modern compass. In the } \\
\text { late 12th century Necame of England and Gio de } \\
\text { Provins of France were the first to describe the } \\
\text { simplest boussole ("compass" in French), a } \\
\text { device intended to determine the magnetic } \\
\text { azimuth. }\end{array}$ \\
\hline 4. & $\begin{array}{l}\text { Middle Ages (early } \\
\text { 14th century) }\end{array}$ & $\begin{array}{l}\text { Europe } \\
\text { (Italy) }\end{array}$ & $\begin{array}{l}\text { Flavio Fioia of Italy refined on the existing } \\
\text { magnetic device (i.e. compass, } 16 \text { rhumbs) }\end{array}$ \\
\hline 5. & $\begin{array}{l}\text { Renaissance } \\
\text { (16th century) }\end{array}$ & Europe & $\begin{array}{l}\text { The compass card was divided into } 32 \text { rhumbs, } \\
\text { and the needle framing was put inside a gimbal to } \\
\text { remove the impact of ship motions }\end{array}$ \\
\hline 6. & $\begin{array}{l}\text { Modern Age } \\
\text { (17th century) }\end{array}$ & Europe & $\begin{array}{l}\text { The compass was equipped with a direction } \\
\text { finder, i.e. a rotating diametric ruler with sighting } \\
\text { devices at the ends with its center based on the } \\
\text { box cover above the needle }\end{array}$ \\
\hline 7. & $\begin{array}{l}\text { Contemporary } \\
\text { history } \\
(1908)\end{array}$ & $\begin{array}{l}\text { Europe } \\
\text { (Germany) }\end{array}$ & $\begin{array}{l}\text { Hermann Anschütz-Kaampfe, a German } \\
\text { engineer, invented the gyroscope }\end{array}$ \\
\hline 8. & $\begin{array}{l}\text { Contemporary } \\
\text { history } \\
(1920)\end{array}$ & Europe & $\begin{array}{l}\text { Plus Fours Routefinder, the first prototype of the } \\
\text { modern navigator in the form of a wrist watch }\end{array}$ \\
\hline 9. & $\begin{array}{l}\text { Contemporary } \\
\text { history } \\
(1930)\end{array}$ & Europe & Iter-Auto, the first in-car navigator \\
\hline 10. & $\begin{array}{l}\text { Contemporary } \\
\text { history } \\
(1966)\end{array}$ & USA & $\begin{array}{l}\text { The first electronic navigation system with the } \\
\text { punched cards technology developed by General } \\
\text { Motors (Driver Aid Information and Routing) }\end{array}$ \\
\hline 11. & $\begin{array}{l}\text { Contemporary } \\
\text { history } \\
(1957)\end{array}$ & USSR & $\begin{array}{l}\text { Launching of first artificial satellite of the Earth } \\
\text { marked the start of the satellite navigation era. }\end{array}$ \\
\hline 12. & $\begin{array}{l}\text { Contemporary } \\
\text { history } \\
(1974-1994)\end{array}$ & USA & $\begin{array}{l}\text { In 1974, the idea of satellite navigation based on } \\
\text { the Doppler Effect was implemented by the US } \\
\text { military which launched the first of the } 24 \text { GPS } \\
\text { satellites to cover the entire area of the Earth. The } \\
\text { last of them was launched in } 1994 \text {. There are } 32 \\
\text { satellites of that kind at the moment. }\end{array}$ \\
\hline 13. & $\begin{array}{l}\text { Contemporary } \\
\text { history } \\
\text { (since 1976) }\end{array}$ & USSR & $\begin{array}{l}\text { Development of the GLONASS project was } \\
\text { officially started in the USSR in 1976, but the } \\
\text { first two satellites however were not launched } \\
\text { until 1984. Similarly to GPS, } 24 \text { satellites are } \\
\text { required to cover the entire area of the Earth, }\end{array}$ \\
\hline 14. & $\begin{array}{l}\text { Contemporary } \\
\text { history } \\
\text { (since 1983) }\end{array}$ & $\begin{array}{l}\text { USA, } \\
\text { USSR }\end{array}$ & $\begin{array}{l}\text { In 1983, following the Soviet Air Force shoot } \\
\text { down a Korean Airline civil aircraft that incurred } \\
\text { into the Soviet Union airspace, it was decided to } \\
\text { create GPS for civil needs. }\end{array}$ \\
\hline
\end{tabular}




\section{Methods}

The Satellite Navigation System (Tables 2 and 3) is an integrated system consisting of equipment placed in space orbit and on the ground and designed to determine the coordinates and trajectory parameters of an object. There is a group of satellites in space orbit with each of them emitting signals in the radiofrequency band [3-4]. Once the signal reaches an object on Earth and is processed, the distance from the object to the satellite is calculated using previously known data (such the location of the satellite). The distance is determined by calculating the formulas of wave propagation in the medium. The waves from the satellites propagate at the speed of light, and the lag between their emission in the space and receipt on Earth is directly proportional to the distance between the object and the satellite [5-6].

Table 2. Types of modern navigation systems.

\begin{tabular}{|l|c|l|}
\hline $\begin{array}{c}\text { Item } \\
\text { No. }\end{array}$ & Navigation system type & \multicolumn{1}{c|}{ System subtypes groups } \\
\hline 1. & Satellite-borne & NAVSTAR (GPS); GLONASSS; Doris etc. \\
\hline 2. & Radio-navigational & $\begin{array}{l}\text { Based on extremely low frequency waves, } \\
\text { medium frequency waves, high frequency waves, } \\
\text { etc. }\end{array}$ \\
\hline 3. & Inertial & Platform INS, platformless INS \\
\hline
\end{tabular}

Table 3. Satellite navigation systems over the periods.

\begin{tabular}{|c|c|c|c|c|}
\hline $\begin{array}{l}\text { Item } \\
\text { No. }\end{array}$ & $\begin{array}{l}\text { Developer } \\
\text { country }\end{array}$ & $\begin{array}{l}\text { Name of the } \\
\text { satellite } \\
\text { navigation } \\
\text { system }\end{array}$ & $\begin{array}{c}\text { Brief description based on the main } \\
\text { parameters }\end{array}$ & $\begin{array}{l}\text { Historical } \\
\text { period }\end{array}$ \\
\hline 1. & USA & Transit & $\begin{array}{l}\text { The system included } 5 \text { satellites in } \\
\text { polar orbits and was originally } \\
\text { intended to periodically offset the } \\
\text { guidance systems of sea-based } \\
\text { ballistic missiles, as well as to correct } \\
\text { the errors of ship inertial navigation } \\
\text { systems under any weather } \\
\text { conditions. The objects location error } \\
\text { is approx. } 25 \mathrm{~m} \text {, location } \\
\text { determination period is 1-3 hours, } \\
\text { and location determination time is } \\
10-16 \text { minute. The TRANSIT system } \\
\text { has developed into GPS }\end{array}$ & $\begin{array}{l}1958- \\
1996\end{array}$ \\
\hline 2. & USSR & Cyclone & $\begin{array}{l}\text { The world's first combined } \\
\text { navigation \& communication satellite } \\
\text { complex. A satellite-borne } \\
\text { transponder was fitted for wireless } \\
\text { communication. With a group of } 6 \\
\text { Parus satellites in orbit, the system } \\
\text { was able to determine plane } \\
\text { coordinates accurate to } 80-100 \\
\text { meters. }\end{array}$ & $\begin{array}{l}1967- \\
1978\end{array}$ \\
\hline 3. & USSR (RF) & Tsikada & $\begin{array}{l}\text { The system included } 4 \text { navigation } \\
\text { satellites at an incline of } 83 \text { degrees } \\
\text { with uniform distribution of orbital } \\
\text { plane along the equator. }\end{array}$ & $\begin{array}{l}1979- \\
1997\end{array}$ \\
\hline 4. & USSR (RF) & Parus & $\begin{array}{l}\text { The systems were used to provide } \\
\text { space communications and navigation }\end{array}$ & $\begin{array}{l}1976- \\
2010\end{array}$ \\
\hline
\end{tabular}




\begin{tabular}{|c|c|c|c|}
\hline & & & $\begin{array}{l}\text { data for submarines and surface } \\
\text { vessels of the Russian Navy. They } \\
\text { form the Cyclone Space Military } \\
\text { Navigation \& Communication } \\
\text { System. The satellites are put into } \\
\text { subpolar orbits at an incline of } 82.9 \\
\text { degrees, perigee altitude of } 970 \mathrm{~km} \\
\text { and apogee altitude of } 1,200 \mathrm{~km} \text {. }\end{array}$ \\
\hline 5. & USA & $\begin{array}{l}\text { NAVSTAR } \\
\text { (GPS) }\end{array}$ & $\begin{array}{l}\text { The development of the US } \\
\text { Department of Defense. The GPS } \\
\text { system provides services on a global } \\
\text { scale. The orbital group initially } \\
\text { consisted of } 24 \text { satellites located in } 6 \\
\text { orbital planes with an inclination of } \\
64.5 \text { degrees to the geostationary orbit } \\
\text { plane. Satellite signals have the } \\
\text { following carrier frequencies: } \\
\text { L1=1575.42 MHz, L2=1227.60 MHz, } \\
\text { L5=1176.45 MHz (the latest models). } \\
\text { The operating GPS wavelength falls } \\
\text { within UHF, which means that the } \\
\text { signal reception level may be severely } \\
\text { degraded by physical obstacles and } \\
\text { magnetic storms. This factor } \\
\text { constitutes the main problem in } \\
\text { precise determination of an object's } \\
\text { location. However, the accuracy may } \\
\text { be increased using signal phase } \\
\text { measurement. } \\
\text { The satellite's data transmission } \\
\text { frequency is } 1575.42 \text { MHz. The data } \\
\text { include: ephemeris - precise orbit and } \\
\text { clock adjustment data for each } \\
\text { satellite; almanac - location data of } \\
\text { the satellite. } \\
\text { There are } 31 \text { GPS satellites currently } \\
\text { in orbit. Each satellite transmits its } \\
\text { unique signature consisting of random } \\
\text { sequence (Pseudo Random Noise } \\
\text { (PRN) code) of } 1,023 \text { units of } 0 \text { 's and } \\
1 \text { 's. } \\
\text { There are } 2 \text { types of PRN code: a P- } \\
\text { code processed by a GPS receiver } \\
\text { with an accuracy of more than } 10 \text { m; } \\
\text { and a C/A-code with an accuracy of } \\
\text { approx. } 20 \text { m. The unique ID is added } \\
\text { in the code to determine the signal- } \\
\text { transmitting satellite and to measure } \\
\text { the signal transit time. }\end{array}$ \\
\hline 6. & USSR (RF) & GLONASS & $\begin{array}{l}\text { The GLONASS satellites are situated } \\
\text { in the medium-altitude circular orbit } \\
\text { at an altitude of } 19,400 \mathrm{~km} \text { with } \\
\text { inclination of } 64.8 \text { degrees and orbital } \\
\text { period of } 11 \text { hours and } 15 \text { minutes. } \\
\text { These satellites continuously emit two } \\
\text { types of navigation signals: a standard } \\
\text { accuracy navigation signal in L1 band }\end{array}$ \\
\hline
\end{tabular}




\begin{tabular}{|c|c|c|c|}
\hline & & & $\begin{array}{l}\text { (1.6 GHz), and a high accuracy } \\
\text { navigation signal in L1 and L2 bands } \\
(1.2 \mathrm{GHz}) \text {. The system exploits } \\
\text { frequency division of channels - each } \\
\text { satellite generates a wave at its own } \\
\text { carrier frequency. The GLONASS } \\
\text { system exploits a differential } \\
\text { movement model. It means } \\
\text { determining the satellite coordinates } \\
\text { at a given point in time requires a } \\
\text { solution to a system of differential } \\
\text { equations using numerical integration. }\end{array}$ \\
\hline 7. & France & Doris & $\begin{array}{l}\text { Designed to meet geodesic and } \\
\text { geophysical requirements }\end{array}$ \\
\hline 8. & $\begin{array}{l}\text { EU } \\
\text { (European } \\
\text { Union) }\end{array}$ & GALILEO & $\begin{array}{l}\text { Provides a unique global Search and } \\
\text { Rescue (SAR) service with an } \\
\text { essential feedback function }\end{array}$ \\
\hline 9. & China & Beidou & $\begin{array}{l}\text { Beidou operates in a test mode and } \\
\text { offers positioning, navigation and } \\
\text { time determination services for China } \\
\text { and "some of its surrounding } \\
\text { regions." }\end{array}$ \\
\hline 10 . & Japan & Quasi-Zenit & $\begin{array}{l}\text { The satellite segment includes } 3 \\
\text { satellites in total. Their orbits will be } \\
\text { chosen to ensure that their sub- } \\
\text { satellite points trace out identical } \\
\text { trajectories on the surface with } \\
\text { identical time intervals. At least one } \\
\text { satellite will always be visible at an } \\
\text { angular altitude of over } 70 \text { degrees in } \\
\text { Japan and Korea. }\end{array}$ \\
\hline
\end{tabular}

The principle of satellite signal generation in the NAVSTAR (GPS) system is as follows: the necessary synchronizing pulses and frequencies are generated as derivatives of the resonant frequency of atomic clock. The pulses are generated by the generators of the carrier frequency at which the satellite signals are transmitted, as well as by the PRN code generator and data generator (Fig. 2) [7-8].

Due to large distances and limited power of the signal that the satellite is capable to generate, information is transmitted digitally as a binary code (bit stream) rather than as an analog signal. Accordingly, the initial analog signal is preliminarily digitized and then converted by modulation into a radio signal with a certain frequency range capable of being received by on-ground devices (due to problems in recognizing LF signals, including background noise). This operation results in the frequency translation of digital signal into the HF range. This allows transceivers to ensure recognition of the required signal from the satellite at a certain frequency [9-10]. Thus, the modulation "lays" the information (digital signal) onto the L1 carrier frequency of a satellite (Table 3) - the information from the satellite is initially modulated by the C/A code (Table 3), then BPSK (binary phase-shift keying) performs modulation by a discrete signal of the L1 carrier frequency, at which the signal can be received by the devices (Figure 3 and 4). 


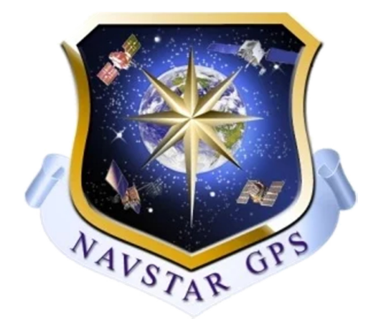

Fig. 1. NAVSTAR GPS logo.

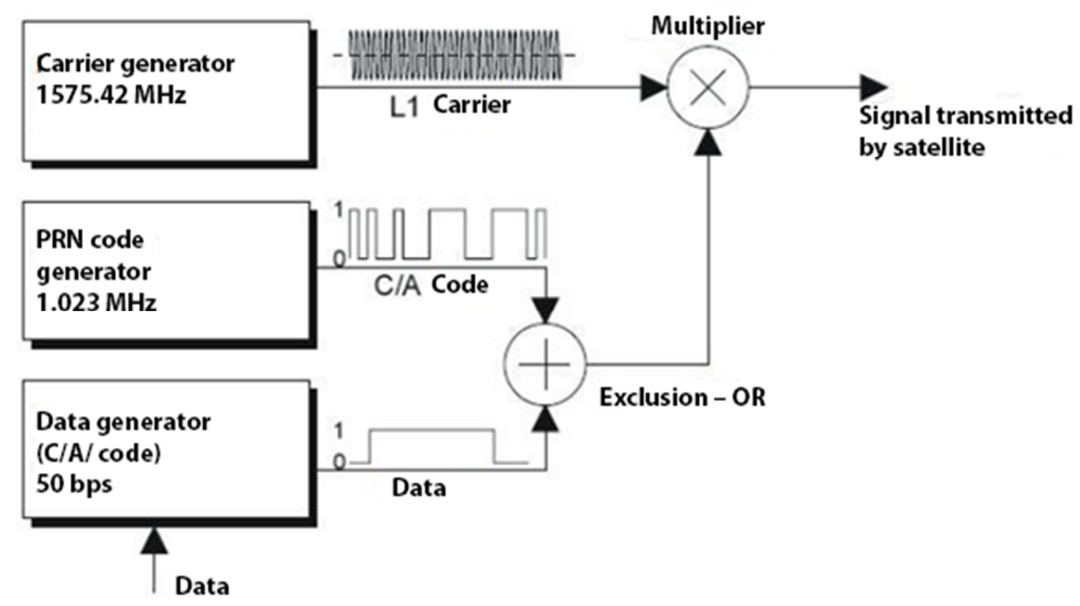

Fig. 2. Simplified block diagram of the satellite signal generation principle.

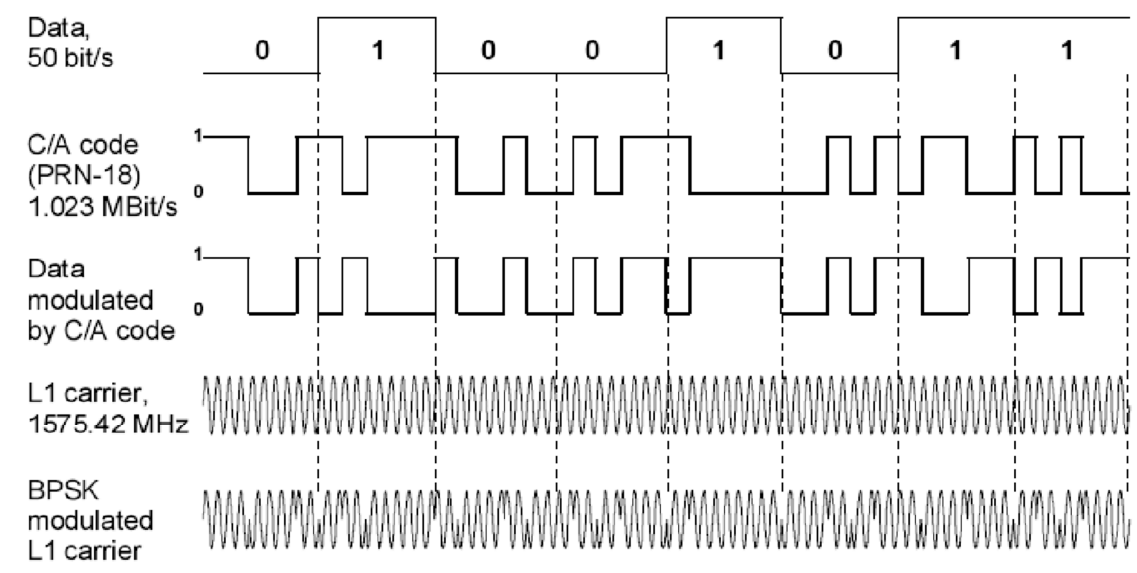

Fig. 3. GPS satellite data structure.

\section{Analog signal}

Digital signal

Radio signal

Fig. 4. Flow chart of analog signal conversion into a signal available for receivers.

To determine the object's coordinates, it is necessary to calculate the transit time for four satellites $\Delta t_{1}, \Delta t_{2}, \Delta t_{3}, \Delta t_{4}$. Distance from the satellite to the object is called the R- 
range. At a given satellite location $X_{\text {Sat }} Y_{\text {Sat }} Z_{\text {Sat }}$, the R-range is calculated for each satellite using the transit time [11-12].

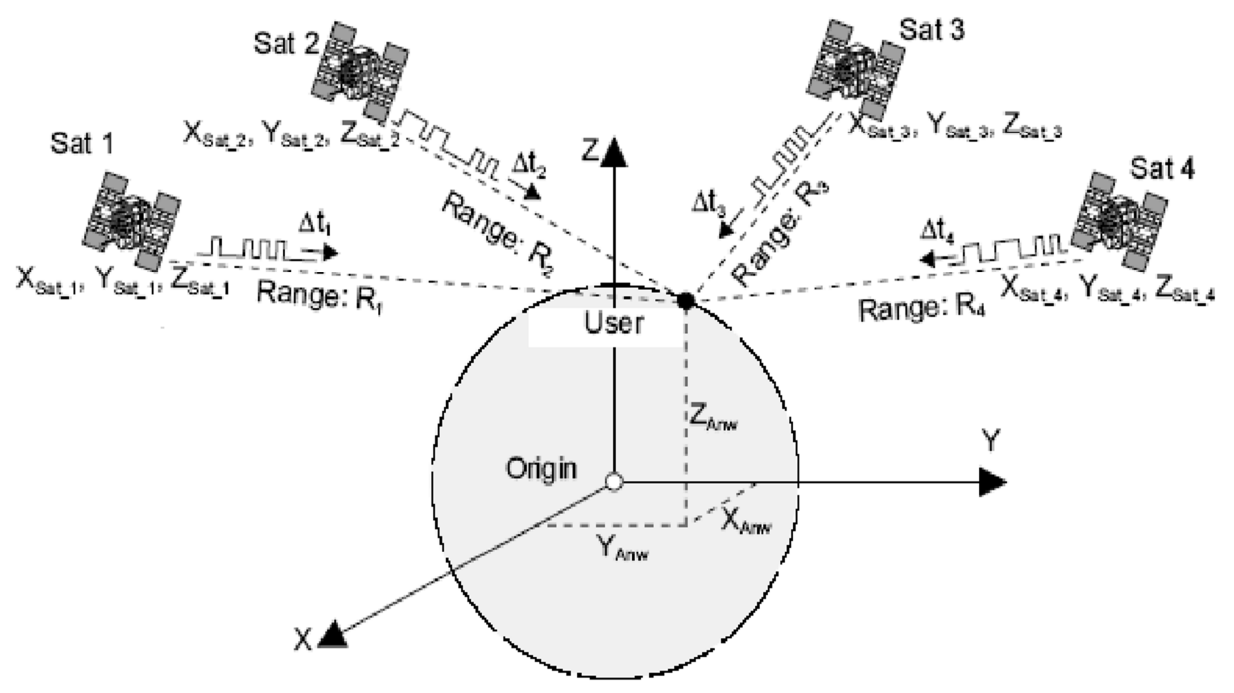

Fig. 5. 3D coordinate system.

Let us assume that a user's clock is not synchronized with UTC (Coordinated Universal Time). Therefore, additional error $\Delta t_{0}$ appears. The result of error allowance for the actual range is called the pseudo-range PSR.

$$
\begin{gathered}
\Delta t_{\text {measured }}=\Delta t+\Delta t_{0} \\
P S R=\Delta t_{\text {measured }} \cdot c=\left(\Delta t_{1}+\Delta t_{0}\right) \cdot c \\
P S R=R+\Delta t_{0} \cdot c
\end{gathered}
$$

Where: $R$ is the actual range from satellite to user; $c$ is the speed of light; $\Delta t_{1} \mathrm{R}$ is the signal transit range from satellite to user; $\Delta t_{0}$ is the difference between satellite's and user's clock; PSR is the pseudo-range [13-14].

The actual range in the Cartesian coordinate system:

$$
R=\sqrt{\left(X_{\text {Sat }}-X_{\text {User }}\right)^{2}+\left(Y_{\text {Sat }}-Y_{\text {User }}\right)^{2}+\left(Z_{\text {Sat }}-Z_{\text {User }}\right)^{2}}
$$

Therefore, the pseudo-range is calculated using the formula:

$$
P S R=\sqrt{\left(X_{\text {Sat }}-X_{\text {User }}\right)^{2}+\left(Y_{\text {Sat }}-Y_{\text {User }}\right)^{2}+\left(Z_{\text {Sat }}-Z_{\text {User }}\right)^{2}}+\Delta t_{0} \cdot c
$$

To determine the four unknown variables $\left(\Delta t_{0}, X_{U s e r}, Y_{U s e r}, Z_{U s e r}\right)$, four independent equations are required.

The following equation holds good for 4 satellites $(i=1 \ldots 4)$

$$
P S R_{i}=\sqrt{\left(X_{\text {Sat } i}-X_{\text {User }}\right)^{2}+\left(Y_{\text {Sat_ } i}-Y_{U s e r}\right)^{2}+\left(Z_{\text {Sat_ } i}-Z_{U s e r}\right)^{2}}+\Delta t_{0} \cdot c
$$




\section{Results}

The following factors comprise the general error in the system: $10 \mathrm{~ns}$ time error of the satellite clock, error in the satellite orbit position, heterogeneity of propagation medium. The table reflects the effect of errors on data accuracy [15-16].

Table 4. Measurement error factors.

\begin{tabular}{|l|l|c|}
\hline $\begin{array}{c}\text { Item } \\
\text { No. }\end{array}$ & \multicolumn{1}{|c|}{ Factor } & Error, $\mathbf{~ m}$ \\
\hline 1. & Ionosphere effect & 4 \\
\hline 2. & Satellite clock & 2.1 \\
\hline 3. & Receiver measurements & 0.5 \\
\hline 4. & Ephemeris data & 2.1 \\
\hline 5. & Troposphere effect & 0.7 \\
\hline 6. & Multi-directivity & 1.4 \\
\hline 7. & General RMS value (non-filtered) & 5.3 \\
\hline 8. & General RMS value (filtered) & 5.1 \\
\hline 9. & Vertical error (1 sigma (68,3\%)VDOP $=2,5)$ & 12.8 \\
\hline 10. & Vertical error (2 sigma (95,5\%)VDOP $=2,5)$ & 25.6 \\
\hline 11. & Horizontal error (1 sigma (68,3\%)HDOP=2,5) & 10.2 \\
\hline 12. & Horizontal error (2 sigma (95,5\%)HDOP $=2,5)$ & 20.4 \\
\hline
\end{tabular}

Originally intended for military purposes only, GPS is used today for civilian applications such as surveillance, navigation (air, sea, and ground), positioning, speed measurement, time detection, control of stationary and moving objects, and so on. The system operator guarantees the standard civil consumer the following accuracy (Tables 5, 6) for $95 \%$ of the time:

Table 5. Accuracy of GPS.

\begin{tabular}{|l|l|c|}
\hline $\begin{array}{c}\text { Item } \\
\text { No. }\end{array}$ & \multicolumn{1}{|c|}{ GPS Accuracy Type } & Value in appropriate units \\
\hline 1. & Horizontal accuracy & $\leq 13 \mathrm{~m}$ \\
\hline 2. & Vertical accuracy & $\leq 22 \mathrm{~m}$ \\
\hline 3. & Time accuracy & $\sim 40 \mathrm{~ns}$ \\
\hline
\end{tabular}

Table 6. Comparative analysis of the two main existing satellite systems.

\begin{tabular}{|c|c|c|c|}
\hline \multirow{2}{*}{$\begin{array}{l}\text { Item } \\
\text { No. }\end{array}$} & \multicolumn{3}{|c|}{ GPS NAVSTAR vs GLONASS } \\
\hline & Parameter & GPS & GLONASS \\
\hline 1. & Signal and its structure & Code division of signals & $\begin{array}{c}\text { Frequency division } \\
\text { of signals }\end{array}$ \\
\hline 2. & $\begin{array}{c}\text { Satellites movement } \\
\text { description }\end{array}$ & Osculating elements model & $\begin{array}{c}\text { Differential } \\
\text { movement model }\end{array}$ \\
\hline 3. & $\begin{array}{c}\text { Construction geometry of } \\
\text { satellites }\end{array}$ & 6 orbital planes, 32 satellites & $\begin{array}{c}3 \text { orbital planes, } 24 \\
\text { satellites }\end{array}$ \\
\hline 4. & Accuracy & $5 \mathrm{~m}$ & $2.5-2.8 \mathrm{~m}$ \\
\hline
\end{tabular}

Despite the worldwide use of the GPS navigation system in various fields of science and technology (including the global construction industry), Analytical Table 6 shows that Russia's GLONASS system has a number of technical advantages resulting in better accuracy of both plane and high-altitude positioning. However, it is the worldwide coverage of GPS that makes it the most popular navigation equipment and software solution. As for the construction industry, let us review the main areas of application of a 
navigation system in tackling applied engineering, transport, management and qualimetry tasks (Table 7).

Table 7. Practical application of navigation in the field of construction supervision and site survey.

\begin{tabular}{|c|c|c|}
\hline $\begin{array}{l}\text { Item } \\
\text { No. }\end{array}$ & Application area & $\begin{array}{l}\text { Implementation effectiveness exemplified by a } \\
\text { specific task solution }\end{array}$ \\
\hline 1. & Construction machinery & $\begin{array}{l}\text { Reduction of construction fleet hijacking rate } \\
\text { (particularly truck mixers, self-propelled cranes, } \\
\text { bulldozers, front loaders and excavators) by means of } \\
\text { specialized GPS trackers }\end{array}$ \\
\hline 2. & Construction machinery & $\begin{array}{l}\text { Construction fleet route tracking (which also means } \\
\text { fuel consumption control) and working time control } \\
\text { by means of specialized GPS trackers }\end{array}$ \\
\hline 3. & Road and airfield construction & $\begin{array}{l}\text { Roadway condition survey; roadway composition } \\
\text { control; road paving monitoring; maintenance vehicles } \\
\text { work optimization; shunting management } \\
\text { optimization }\end{array}$ \\
\hline 4. & $\begin{array}{l}\text { Construction of engineering } \\
\text { infrastructure }\end{array}$ & $\begin{array}{l}\text { High-precision laying of linear infrastructure (e.g. } \\
\text { laying, inspection and monitoring of utility networks } \\
\text { and systems) }\end{array}$ \\
\hline 5. & $\begin{array}{l}\text { Inspection of buildings, } \\
\text { structures and other facilities }\end{array}$ & $\begin{array}{l}\text { Measurement work; monitoring of buildings and } \\
\text { structures using the navigation field of global } \\
\text { navigation satellite systems (GNSS) }\end{array}$ \\
\hline 6. & $\begin{array}{l}\text { Inspection of buildings, } \\
\text { structures and other facilities }\end{array}$ & $\begin{array}{l}\text { Local flaw detection of construction objects, including } \\
\text { generation of defect lists }\end{array}$ \\
\hline 7. & $\begin{array}{l}\text { Construction supervision and } \\
\text { operation of the Technical } \\
\text { Customer services }\end{array}$ & $\begin{array}{l}\text { In-process quality control of construction products. } \\
\text { Quality control of finished construction products. } \\
\text { Verification of the on-site construction and installation } \\
\text { work progress (factual completion, in some cases - } \\
\text { work progress in numerical form). } \\
\text { Control service engineer work optimization and } \\
\text { automation. } \\
\text { Generation of a defect database for a facility. }\end{array}$ \\
\hline 8. & $\begin{array}{l}\text { Geodesic support of } \\
\text { construction and inspection of } \\
\text { buildings and structures }\end{array}$ & $\begin{array}{l}\text { Geodetic work using appropriate technologies; in-field } \\
\text { positioning and object snapping; satellite geodesy } \\
\text { methods in high-rise buildings construction }\end{array}$ \\
\hline 9. & $\begin{array}{l}\text { Construction and installation } \\
\text { works at industrial and civil } \\
\text { construction projects }\end{array}$ & $\begin{array}{l}\text { Earthworks quality and volume control using } \\
\text { machinery fitted with satellite signal receivers (e.g. } \\
\text { bulldozers with 3D leveling system); relative } \\
\text { movement control }\end{array}$ \\
\hline 10. & Cadastral work & Measurement work \\
\hline 11. & $\begin{array}{l}\text { Construction of underground } \\
\text { mass transit facilities }\end{array}$ & Geodesic and surveying work \\
\hline 12. & Bridge construction & Relative movement control \\
\hline
\end{tabular}

Geodesic methods based on satellite navigation are widely used in building supervision. They ensure a high accuracy, while on-line in-field positioning accelerates field work because there is no need to provide any extra geodetic control networks which involve reference points transfer. Based on the principles of global navigation satellite systems (GNSS), integrated software systems are being developed for the qualimetric needs of control procedures in the construction and inspection of existing buildings and structures; such systems include defect detection systems with a positioning function on extended objects (Fig. 6) and technical condition monitoring using GNSS.

Integrated construction supervision using GNSS may include the following operations:

- Construction expertise 
- Quality, volume and cost inspection of construction and installation works

- Pre-design inspection of projects and land plots

- Executive documentation control

- Designer's field supervision

- $\quad$ Recording of the actual state of facilities and construction site

- Work completion time monitoring

- Pre-insurance and insurance inspection of facilities

- $\quad$ Certification of buildings and structures

- Facilities inspection in evaluation operations

- etc.

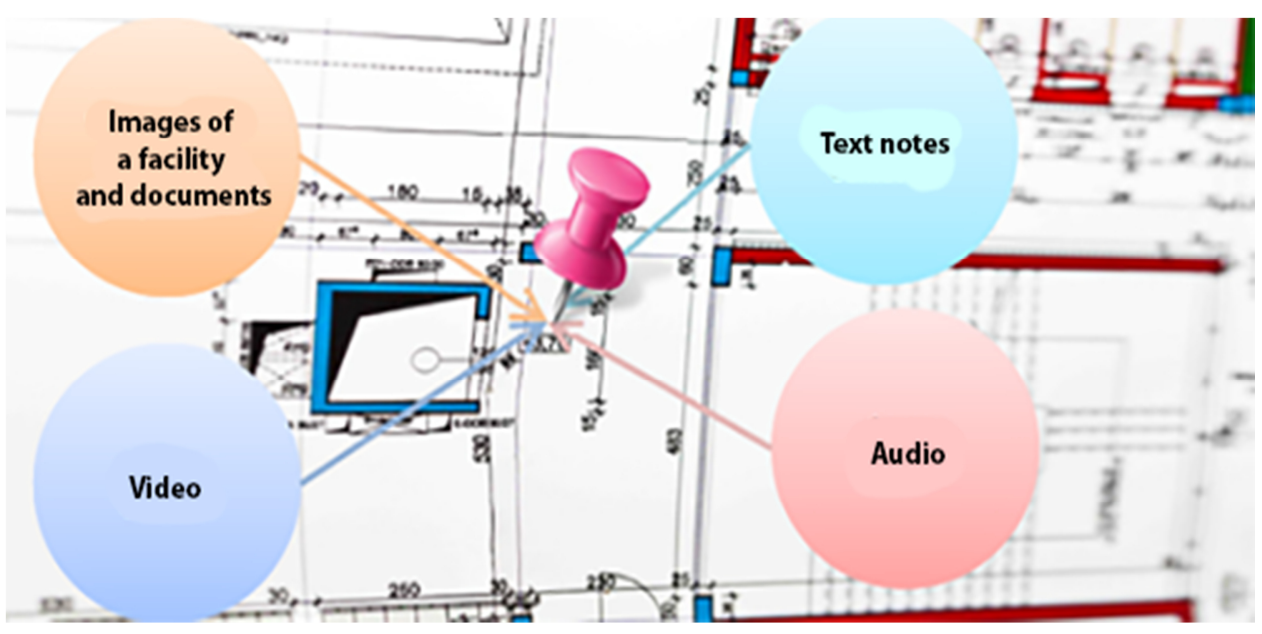

Fig. 6. Opportunities of placing defect tags and other comments on the plan of a relevant drawing when conducting building supervision of a facility using the integrated engineering software of Construction Inspection and Technical Supervision (with a function of downloading information to mobile devices and computers).

\section{Conclusions}

Despite available high-precision advanced technologies, there are a number of difficulties related to establishing the maximum measurement accuracy in the matters of global satellite support in tackling engineering problems. Satellite navigation systems alone (neither GPS nor GLONASS, which is in fact more accurate) are incapable of providing sufficient accuracy for construction needs due to a number of specific physical and technical features (including those previously discussed in this article). For this reason there is a need for indirect geodetic instruments to ensure more accurate positioning. The use of satellite navigation basics in geodesy has significantly expanded the range of verification capabilities in construction control and monitoring of the technical condition of buildings and structures, from monitoring fluctuations in high-rise buildings to verifying the progress of construction and installation work at the stage of delivery of completed construction products by the General Contractor.

\section{References}

1. I.A. Lipkin, Satellite Navigation Systems (Vuz. Book, Moscow, 2001) 
2. E. Povalyaev, S. Khutornoy, CHIP NEWS. Engineering Microelectronics 1, 5-12 (2002)

3. A.V. Bataev, A.B. Mottaeva, E.Y. Vasilyeva, Proceedings of the 34th International Business Information Management Association Conference (IBIMA)-2019, Vision 2025: Education Excellence and Management of Innovations through Sustainable Economic Competitive Advantage of 14015, 277-287 (2019)

4. I.A. Rudkova, Youth and Science: A Collection of Materials of the VIII All-Russian Scientific and Technical Conference of Students, Postgraduates and Young Scientists dedicated to the 155th anniversary of K. E. Tsiolkovsky (Siberian Federal University, Krasnoyarsk, 2012) http://conf.sfu-kras.ru/sites/mn2012/section35.html

5. Yu.A. Soloviev, Gyroscopy and navigation 4(43), 146 (2003)

6. D.V. Topchiy, A.I. Tokarski, System Engineering construction. Cyberphysical building systems Collection of materials of the seminar held in the framework of the VI International scientific conference, 234-238 (2018)

7. D.V. Topchiy, E.O. Kokurina, Prospects of science 1(100), 31-36 (2018)

8. D.V. Topchiy, E.O. Kachurina, Prospects of science 10(109), 110-114 (2018)

9. D.V. Topchiy, A.Yu. Yurgaitis, V.S. Chernigov, E.O. Kochurina, System technology 3(28), 140-148 (2018)

10. D.V. Topchy, International Journal of Civil Engineering and Technology 9(7), 19751986 (2018)

11. D.V. Topchiy, E.O. Kochurina, A.A. Zalmanov, Technology and organization of construction production 1(11), 7-10 (2016)

12. D.V. Topchiy, Innovative technologies in the construction and geoecology proceedings of the II International scientific-practical conference (St. Petersburg state transport University named after Emperor Alexander I, 2015)

13. Yu.A. Soloviev, Satellite navigation systems (Eco-Trends, Moscow, 2000)

14. Yu.A. Soloviev, Satellite navigation and its applications (Eco-Trends, Moscow, 2003)

15. K.M. Antonovich, A.P. Karpik, Geodesy and Cartography 4 (2003)

16. P. Oleinik, A. Yurgaytis, MATEC Web of Conferences 117, 00130 (2017) https://doi.org/10.1051/matecconf/201711700130 